\title{
SISTEM LAYANAN KONSUMEN UNTUK USAHA SKALA KECIL DAN MENENGAH (UKM) JASA PENCUCIAN DENGAN METODE BASIS DATA TERDISTRIBUSI
}

\author{
Slamet Risnanto \\ Program Studi Teknik Informatika \\ Universitas Sangga Buana YPKP Bandung \\ Slamet.risnanto@usbypkp.ac.id
}

\begin{abstract}
Abstrak
Penerapan teknologi Informasi di berbagai bidang kehidupan manusia khususnya dibidang usaha sudah sangat penting diimplementasikan, Sistem layanan konsumen untuk usaha skala kecil dan menengah (UKM) jasa pencucian (laundry) ini dapat dijadikan alat bantu yang strategis dalam usaha tersebut, hampir semua jenis layanan jasa laundry pada umumnya bisa disuport oleh sistem layanan ini. Tahapan analisis dan implementasi dilakukan dilakukan secara langsung di delapan usaha laundry dengan berbagai level usaha dan jenis layanan sehingga memperkaya kehandalan, kelengkapan dan fasilitas sistem

Untuk usaha laundry yang mempunyai banyak konter dan cabang diberbagai kota atau Negara, sistem ini bisa mensuport hal tersebut dengan metode basis data terdistribusi, selama konter atau cabang tersebut bisa koneksi internet sehingga level manajemen atau pemilik usaha bisa mengakes data dan laporan dimanapun berada.
\end{abstract}

Kata kunci : layanan konsumen, laundry, data terdistribusi

\section{Pendahuluan}

\subsection{Latar Belakang}

Usaha jasa pencucian atau lebih dikenal dengan istilah laundry semakin berkembang di berbagai lokasi dikota-kota besar dan daerah, terutama yang berdekatan dengan kampus ${ }^{[1]}$, kos-kosan mahasiswa/mahasiswi dan perkatoran, Menggunakan jasa laundry sudah menjadi gaya hidup masyarakat saat ini dengan berbagai alasan, ingin serba praktis, karena kesibukan baik sebagai mahasiswa maupun pekerja kantoran

Seiring dengan perkembangan teknologi informasi dan komunikasi yang sangat pesat di kurun waktu sepuluh tahun terakhir ini akan sangat membantu apabila wirausaha jasa laundry ini dalam hal pengelolaan data transaksi dan lain menggunakan teknologi informasi dan komunikasi sehingga dalam hal melayani konsumen dan pembuatan laporan akan memperkecil kesalahan dan disisi waktu dan sumber daya lebih efektif dan efisien

\subsection{Tujuan}

Tujuan dari membangun sistem ini adalah membantu usaha kecil dan menengah dibidang jasa laundry untuk menerapkan teknologi informasi dan komunikasi dalam usahanya serta mempermudah , meminimalisasi permasalahan yang ada dan meningkatkan efisiensi di segi waktu dan biaya sehinga menjadikan proses pelayanan konsumen di usaha laundry skala kecil dan menengah dengan kualitas yang lebih baik.

\subsection{Ruang Lingkup}

Secara garis besar, sistem layanan konsumen untuk usaha jasa pencucian untuk skala kecil dan menengah dengan metode pendistribusian data sistem tersebar ini mencakup:

1. Perancangan sistem sampai sistem yang siap pakai

2. Aplikasi penerimaan dan pengambilan barang cucian dengan variasi layanan seperti reguler, kiloan, cuci sendiri / selfservice maupun korporat / hotel

3. Pengiriman informasi melalui SMS kepada konsumen

4. Berbagai Laporan

\section{Tinjauan Pustaka}

\subsection{Sistem}

Sistem adalah kumpulan/group dari sub sistem/bagian/komponen apapun baik phisik 
ataupun non phisik yang saling berhubungan satu sama lain dan bekerja sama secara harmonis untuk mencapai satu tujuan tertentu ${ }^{[2]}$ , Sistem adalah kumpulan elemen yang saling berinteraksi dalam suatu kesatuan untuk menjalankan suatu proses pencapaian suatu tujuan utama ${ }^{[3]}$, Sistem dapat di definisikan dengan pendekatan prosedur dan dengan pendekatan komponen, Sistem dan prosedur merupakan suatu kesatuan yang tidak dapat dipisahkan satu sama lain. Suatu sistem baru bisa terbentuk bila di dalamnya terdapat beberapa prosedur yang mengikutinya ${ }^{[4]}$.

\subsection{Konsumen}

Konsumen adalah seorang individu atau kelompok yang membeli produk fisik ataupun jasa dengan mempertimbangkan berbagai macam faktor seperti harga, kualitas, tempat, pelayanan dan sebagainya berdasarkan keputusan mereka sendiri, konsumen adalah semua orang yang membeli suatu produk tertentu baik berupa barang maupun jasa ${ }^{[5]}$.

\subsection{Usaha Kecil dan Menengah (UKM)}

Definisi UKM menurut Kementrian Negara Koperasi dan Usaha Kecil Menengah (Kemenkop dan UKM) bahwa yang dimaksud dengan usaha kecil (UK) termasuk usaha Mikro (UMI) adalah entitas usaha yang mempunyai memiliki kekayaan bersih paling banyak Rp. 200.000.000 tidak termasuk tanah dan bangunan tempat usaha dan memiliki penjualan tahunan paling banyak Rp. 1.000.000.000 sedangkan usaha menengah merupakan entitas usaha milik warga Negara Indonesia yang memiliki kekayaan bersih lebih besar dari Rp. 200.000.000 hingga Rp 10.000.000.000 tidak termasuk tanah dan bangunan

Definisi menurut badan pusat statistik (BPS) memberikan definisi UKM berdasarkan kuantitas tenaga kerja yaitu usaha kecil merupakan entitas usaha yang memiliki jumlah tenaga kerja 5 hungga 19 orang, sedangkan usaha menengah memiliki tenaga kerja 20 hingga 99 orang.

\subsection{Basis Data terdistribusi}

Basis data terdistribusi (distributed database) adalah suatu basis data yang berada di bawah kendali sistem manajemen basis data (DBMS) terpusat dengan peranti penyimpanan (storage devices) yang terpisah-pisah satu dari yang lainnya. Tempat penyimpanan ini dapat berada di satu lokasi yang secara fisik berdekatan (misal: dalam satu bangunan) atau terpisah oleh jarak yang jauh dan terhubung melalui jaringan internet. Penggunaan basis data terdistribusi dapat dilakukan di server internet, intranet atau ekstranet kantor, atau di jaringan perusahaan

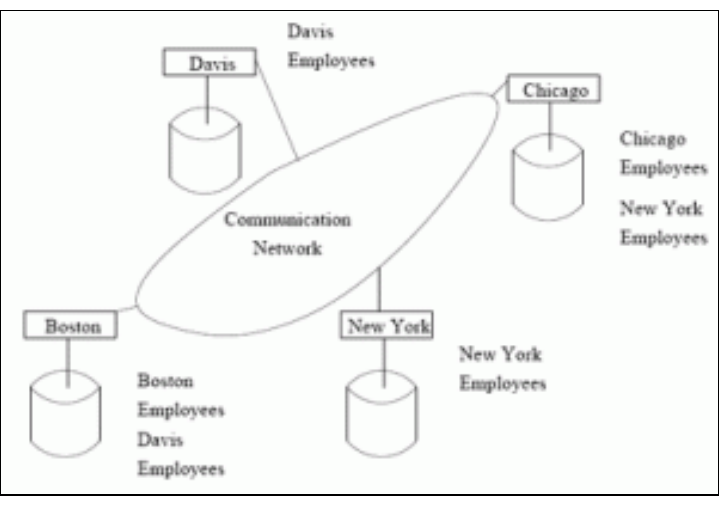

Gambar 1 : Ilustrasi basis data terdistribusi

\section{Pembahasan}

\subsection{Analisis Sistem dan bisnis proses}

Analisis sistem dilakukan dengan melakukan riset terhadap tujuh perusahaan laundry berskala kecil dan menengan untuk mengumpulkan dan membuat perbandingan bisnis proses yang ada di perusahaan-perusahaan laundry tersebut sehingga bisa mengambil garis tengah kebutuhan sistem umumnya perusahaan laundry, kesimpulan bisnis proses dari hasil riset ke tujuh perusahaan laundry tersebut adalah sebagai berikut

1. Konsumen datang membawa barang yang akan dicuci ke perusahaan laundry selanjutnya petugas layanan konsumen akan memeriksa barang tersebut, menuliskan noda-noda dan kerusakankerusakan di kertas anti air yang disebut dengan istilah marker dan ditempelkan ke barang yang akan dicuci dan terakhir petugas layanan konsumen membuatkan invoice untuk konsumen yang dipakai sebagai tanda terima barang, pembayaran dan untuk pengambilan apabila barang sudah selesai di cuci

2. Selain konsumen sendiri yang datang ke perusahaan laundry, ada layanan dengan istilah "Pickup - Delivery", dimana pegawai perusahaan mendatangi konsumen untuk mengambil sekaligus mengirimkan barang cucian dan hasil cucian, pembuatan bon dilakukan di 
tempat konsumen sedangkan pembuatan dan penempelan marker dilakukan di perusahaan laundry

3. Perusahaan laundry akan segera melakukan proses cuci, setrika, pengepakan dan terakhir disimpan di konter sebagai barang yang sudah selesai proses cuci atau dikirimkan ke konsumen apabila menggunakan layanan pickup - delivery

\subsection{Analisis kelemahan sistem}

Analisis kelemahan disini bermaksud untuk menganalisa kelemahan-kelamahan sistem yang sedang berjalan dari bisnis proses ketujuh perusahaan laundry tersebut, kesimpulan dari kelemahan sistem yang sedang berjalan tersebut adalah sebagai berikut :

1. Proses pemeriksaan barang yang akan dicuci, pembuatan marker dan invoice relatif lama sehingga akan menimbulkan antrian yang panjang apabila ada konsumen lain yang datang dalam waktu bersamaan

2. Proses pengambilan barang yang sudah selesai cuci oleh konsumen prosesnya relatif lama karena petugas layanan konsumen akan memeriksa secara manual apakah barang sudah selesai cuci dan dimana tempat penyimpanannya

3. Tidak sedikit para konsumen yang datang sebelum barang cucian selesai atau lupa bahwa sedang melaksanakan order cuci di perusahaan laundry sehingga banyak barang yang sudah selesai cuci tidak diambil oleh konsumen sehingga menimbulkan penumpukan barang dan pendapatan perusahaan tidak tertagihkan

4. Dalam hal pelaporan, karena sistemnya manual, proses pembuatan relatif lama

5. Dalam hal otorisasi dan keamanan transaksi, dimana pembatalan transaksi karena batal cuci atau salah input data adalah otoritas manager sedangkan manager tidak selalu ada di tempat sehingga membutuhkan waktu lama untuk menunggu pembatalan tersebut

6. Kendala lain dimana sebagian besar perusahaan laundry mempunyai banyak konter atau cabang, untuk menerapkan pembagian konsumen pelanggan atau bukan sehingga harga layanan berbeda dan konsumen akan mendatangi konter atau cabang tidak hanya ke konter itu itu saja

\subsection{Analisis Kebutuhan}

Dari analisis bisnis proses dan analisis kelemahan, dapat disimpulkan kebutuhan sistem yang akan dibangun, diantaranya sebagai berikut

1. Aplikasi master konsumen, harus bisa membedakan konsumen pelanggan dan bukan sehingga ketika melakukan transaksi, sistem automatis memberikan harga yang sesuai dengan identitas konsumen tersebut

2. Aplikasi master harga dan noda/kerusakan, untuk mempermudah dan membakukan nama barang, harga dan noda/kerusakan

3. Aplikasi penerimaan barang dari konsumen yang akan dicuci, dimana aplikasi tersebut harus secara mudah bisa mencari data konsumen, data harga dan data noda atau kerusakan dan selanjutnya bisa mencetak invoice dan marker

4. Aplikasi penerimaan barang dengan layanan berbeda diantaranya layanan regular, kiloan, layanan koin dan layanan korporat seperti perusahaan atau hotel yang tentunya mempunyai harga dan tindakan yang berbeda

5. Aplikasi selesai cuci, aplikasi ini berguna untuk menandai barang yang sudah selesai cuci termasuk tempat penyimpanannya sehingga petugas layanan konsumen bisa mudah mencarinya selanjutnya aplikasi ini harus bisa secara automatis memberikan informasi berupa pesan teks kepada konsumen

6. Aplikasi pengambilan barang, berguna untuk menandai barang yang sudah diambil oleh konsumen, aplikasi ini dipakai pada waktu konsumen mengambil barang yang selesai cuci

7. Aplikasi pelaporan yang biasa variatif dari hasil transaksi-transaksi diatas seperti pendapatan perhari, perbulan dan pertahun, stock opname dan lain lain

8. Kebutuhan komunikasi data yang tersebar dimana sebagian besar perusahaan laundry mempunyai banyak 
konter/cabang sehingga mempermudah mengelola data

9. Kebutuhan Fasilitas pengiriman SMS kepada pelanggan untuk memberitahukan informasi bahwa order sudah selesai dan pengiriman SMS kepada manager atau pemilik laundry sebagai informasi omjet transaksi

10. Kebutuhan system dengan fasilitas layanan lain seperti order cucian dari korporat seperti hotel dan laundry lain, layanan kiloan dan layanan menggunakan koin

\subsection{Desain Sistem dan basis data}

Desain sistem diperlukan untuk menentukan sejauh mana analisis kebutuhan akan diterapkan dalam sistem, apa yang akan disajikan oleh sistem dan bagaimana rancangan basis data baik untuk sistem yang akan dibangun yang sesuai dengan kaidah kaidah perancangan basis data, berikut desain sistem yang akan dibangun

\section{Use Case diagram}

Use case diagram adalah abstraksi dari interaksi antara sistem dan actor, use case memberikan pesifikasi fungsi-fungsi yang ditawarkan oleh sistem dari perspektif user, berikut ini use case dari sistem yang akan dibangun

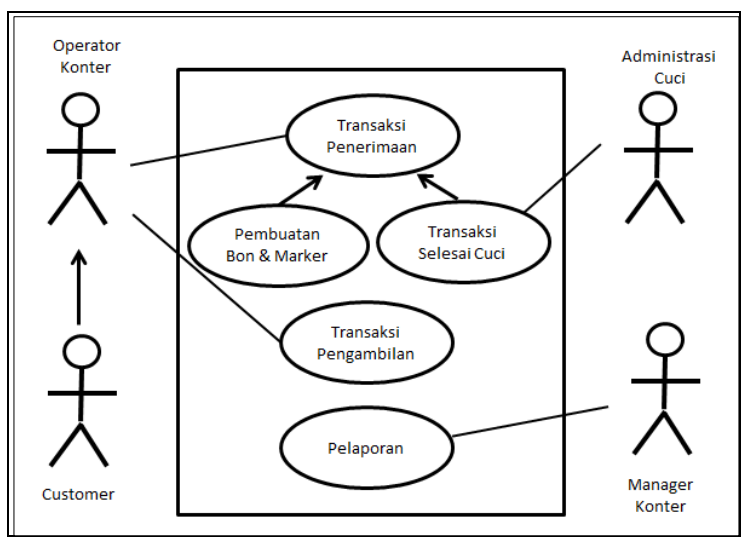

Gambar 2 : Use Case Layanan Reguler \& Kiloan

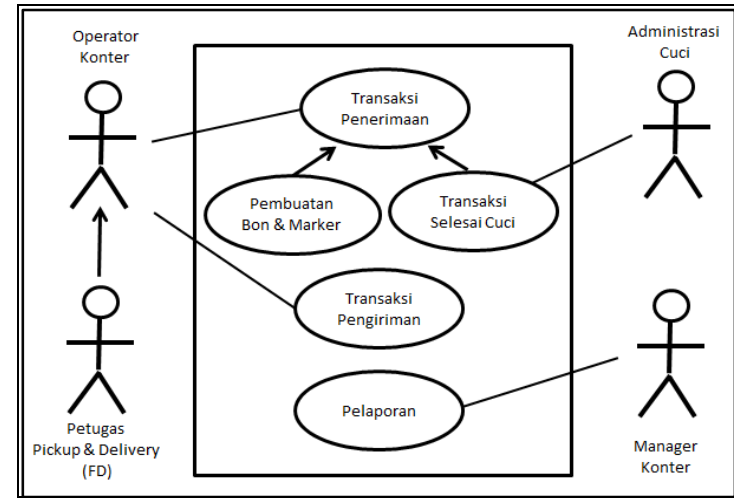

Gambar 3 : User case layanan Korporat

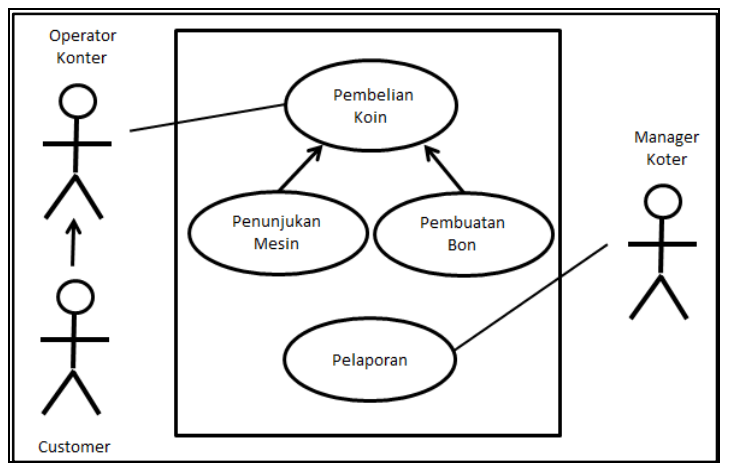

Gambar 4 : Use Case layanan Koin 


\section{Desain Basis Data}

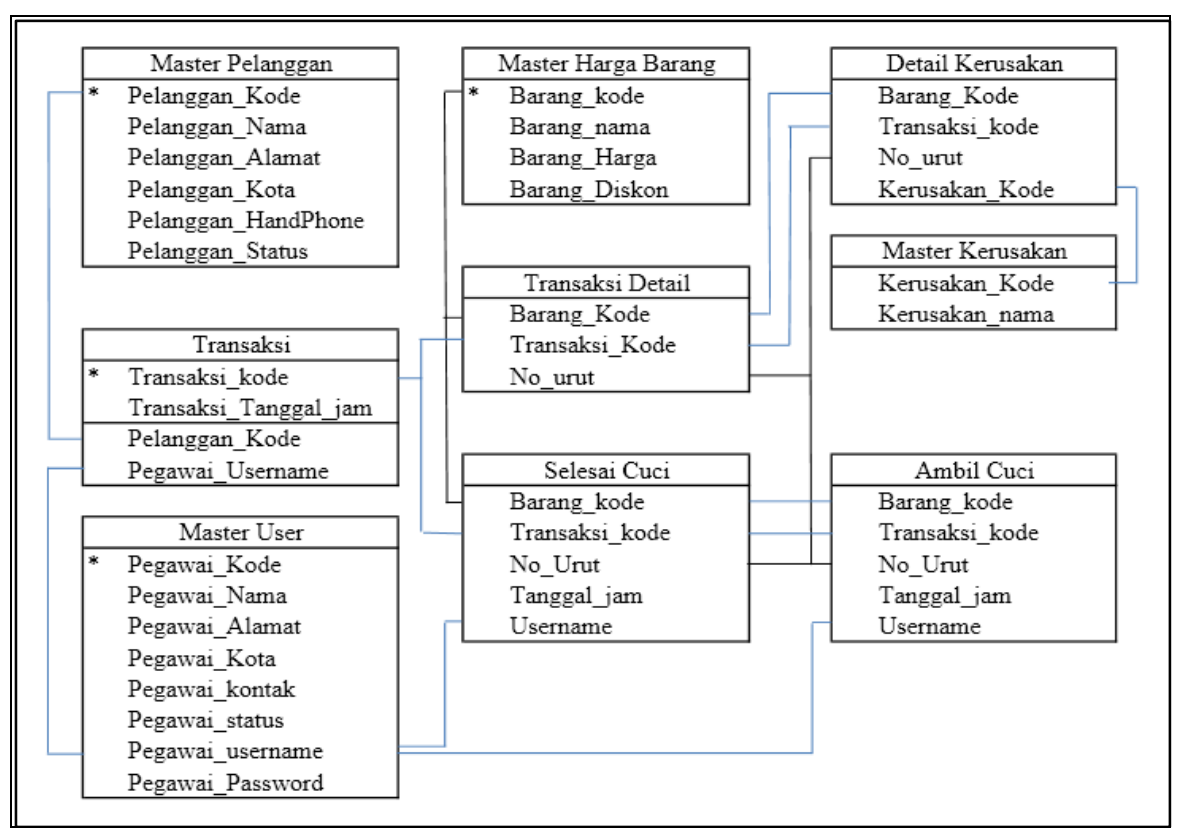

Gambar 5 : Desain Basis Data layanan Reguler \& Korporat

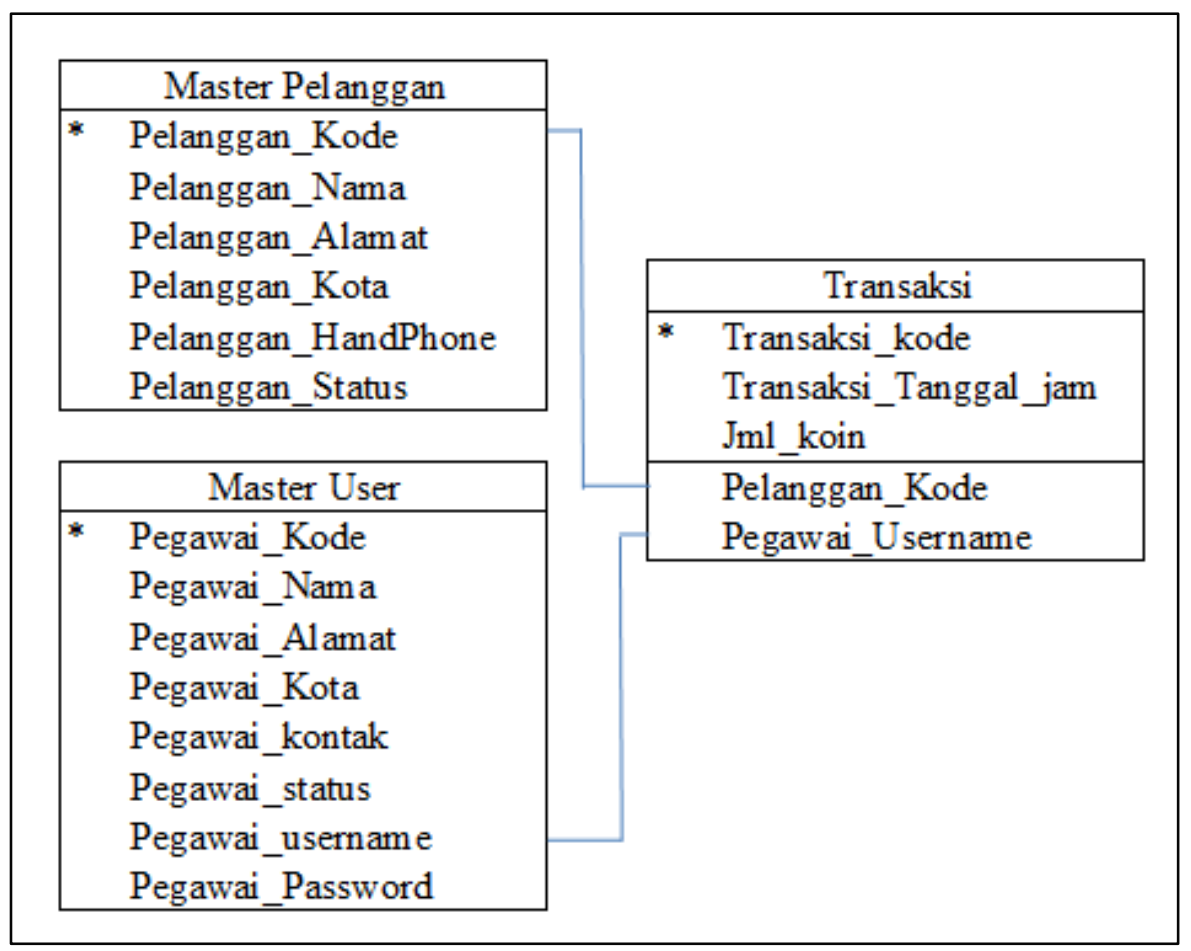

Gambar 6 : Desain basis data layanan Koin 


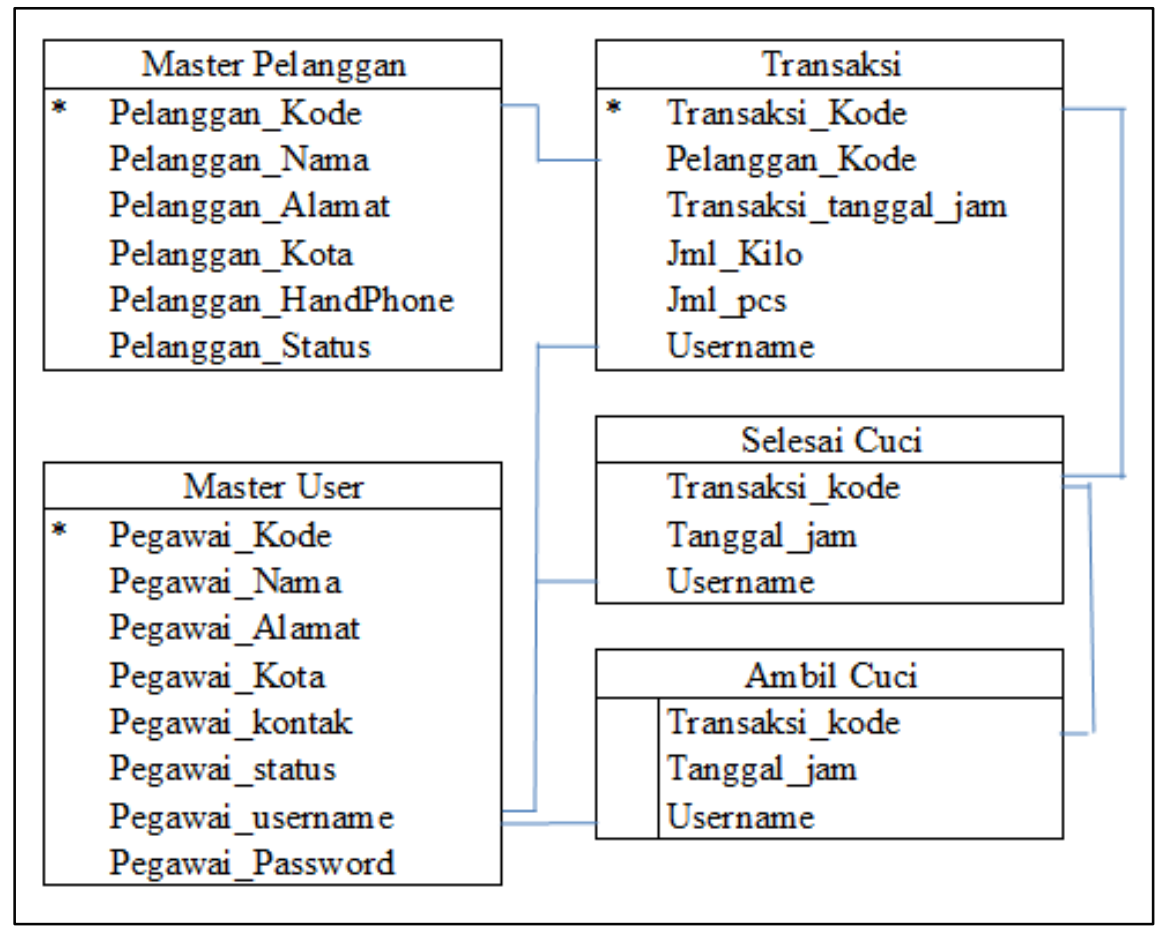

Gambar 7 : Desain basi data layanan Kiloan

\section{Desain Arsitektur Perangkat Keras}

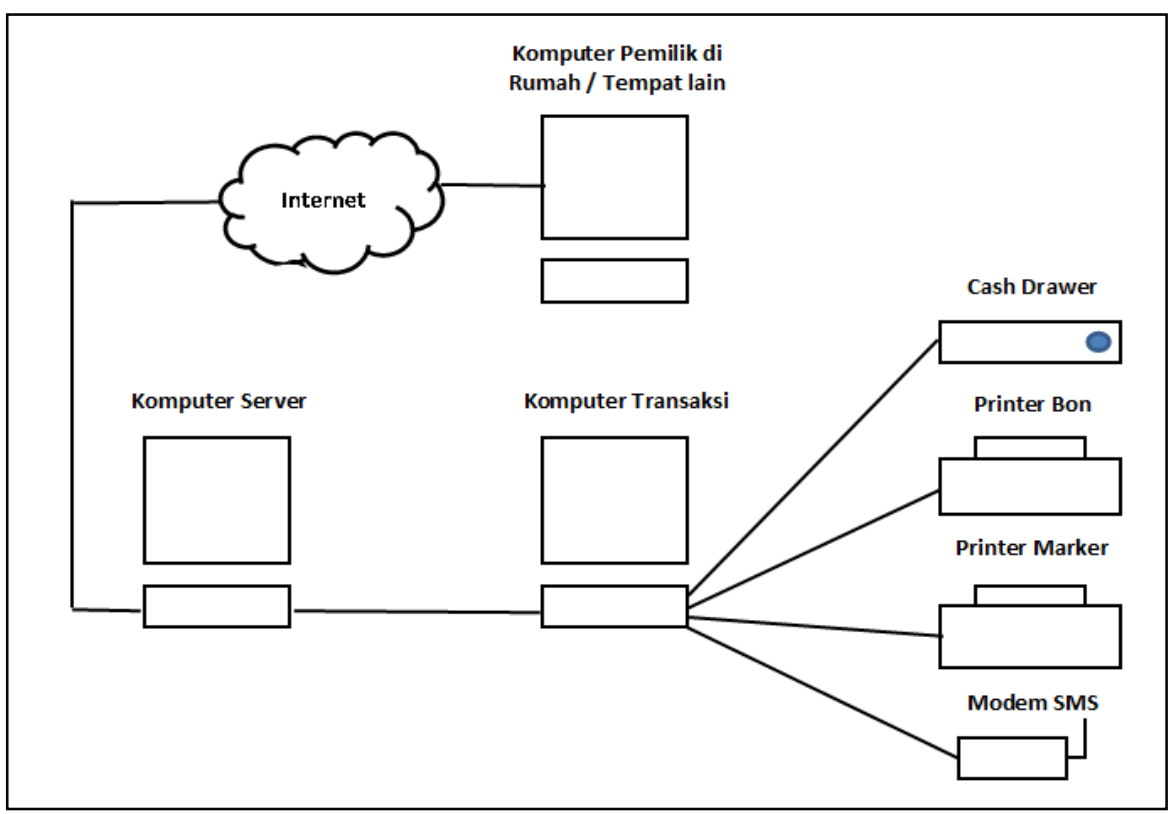

Gambar 8 : Desain Arsitektur Perangkat Keras satu konter 


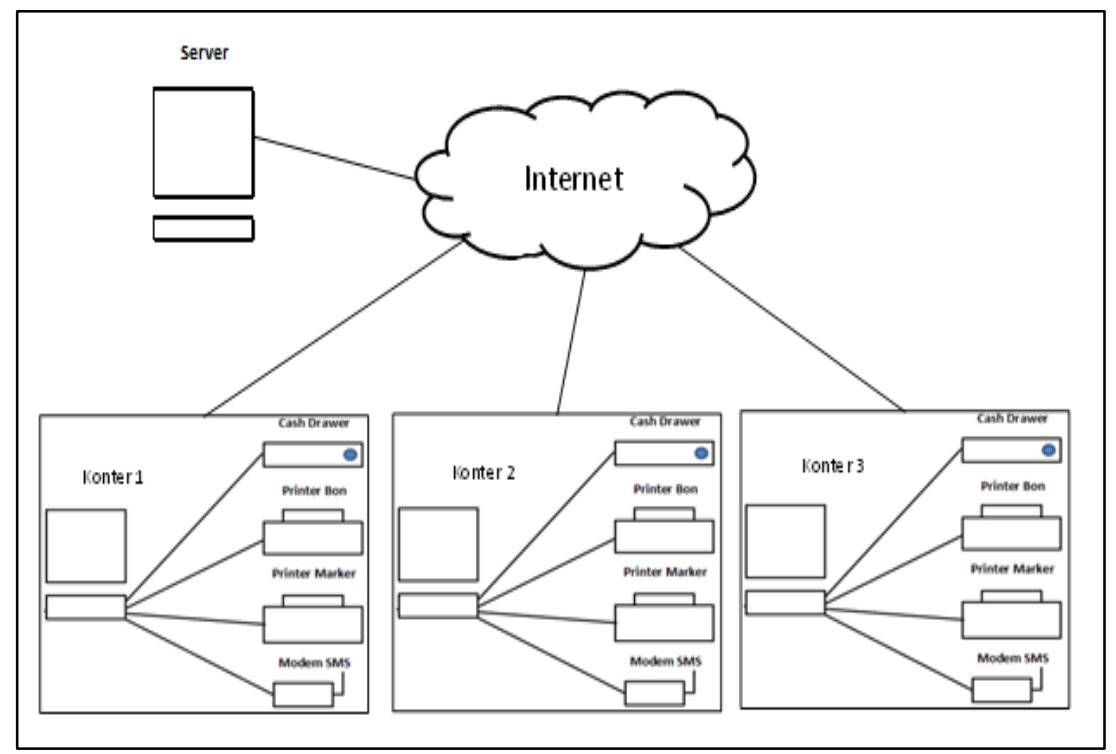

Gambar 9 : Desain Arsitektur Perangkat keras dengan data tersebar

\subsection{Implementasi}

Implementasi sistem layanan konsumen jasa laundry dilakukan dengan menggunakan Visual Studio .net 2010 dan basis data menggunakan MySQL serta desain laporan menggunakan CristalReport 2010 sehingga sistem ini hanya bisa berjalan di sistem operasi Microsoft Windows dengan minimal versi Windows XP
Implementasi dalam hal pengujian dilakukan di beberapa usaha laundry pada skala kecil, menengah dan besar diantaranya Hade Laundry, Elite laundry, Big Laundry, Dresscare Laundry, Lafontaine Laundry dan Speede Laundry,Edwash laundry, Sparkling Laundry, hal ini dilakukan untuk memperkaya kehandalan dan fasilitas sistem sehingga telah teruji dan bisa dipakai di usaha laundry pada umumnya, hasil dari implementasi tersebut diantaranya:

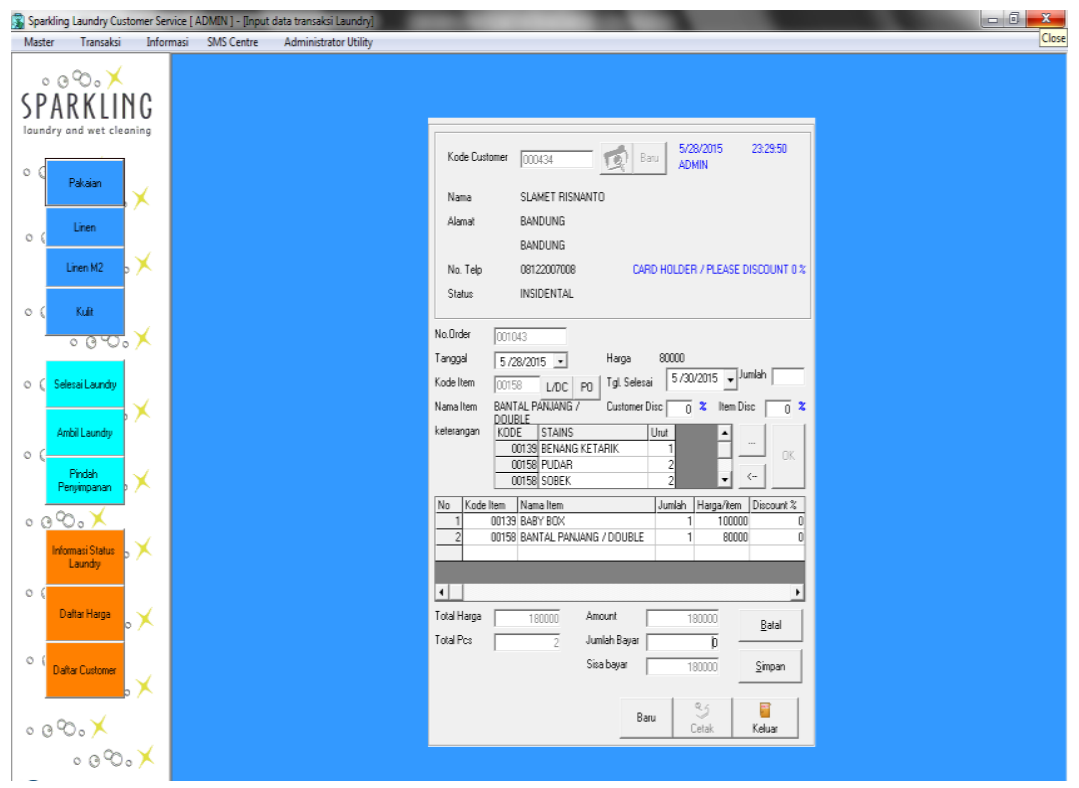

Gambar 10 : Contoh antar muka sistem 


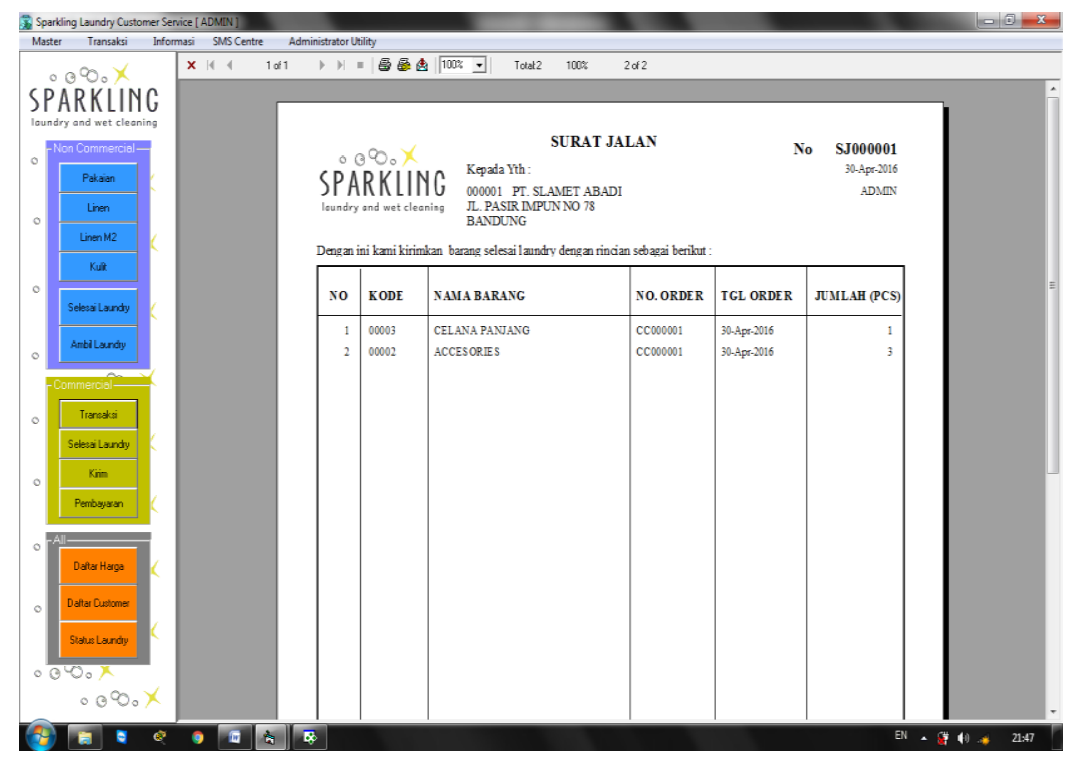

Gambar 11 : Contoh Antar muka sistem

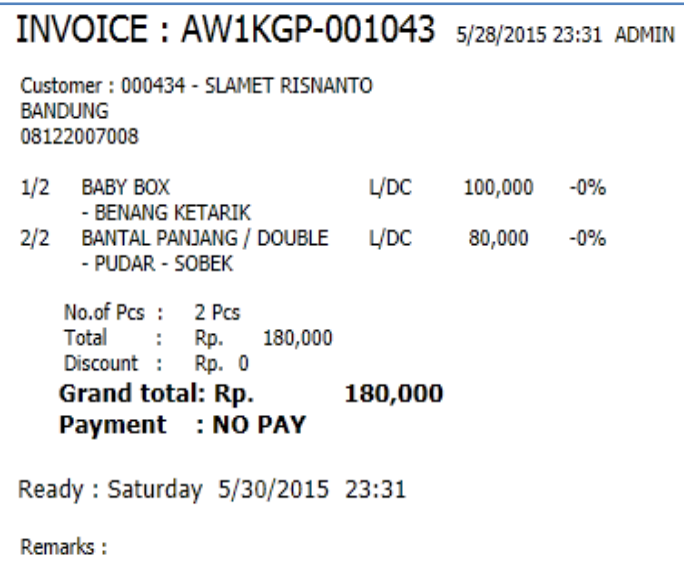

Gambar 12 : Contoh Invoice

HADE Maskumambang >> Data hari ini Kamis tanggal 28/05/2015 Omzet : Rp. $985.000 / 30$ Pcs , Total Omzet bulan ini : Rp. 36.411.660 / 1284 Pcs

Gambar 13 : SMS Automatis

\section{Kesimpulan}

Berdasarkan analisis dan implementasi diatas dapat disimpulkan bahwa :

1. sistem layanan konsumen laundry ini bisa dipakai oleh laundy-laundry dengan berbagai macam layanan pada umumnya ditambah dengan fasilitas pengiriman SMS kepada pelanggan dan pemilik serta bisa dipakai oleh

2. laundry yang mempunyai banyak cabang dengan fasilitas sistem tersebar

3. Sistem layanan konsumen laundry ini sudah teruji kehandalannya karena telah dipakai oleh 8 (delapan) perusahaan laundry sekala besar dan menengah di berbagai kota di Indonesia

\section{Rencana Selanjutnya}

Rencana selanjutnya adalah mengembangkan sistem ini dengan spesifikasi lebih lengkap diantaranya dengan bahasa pemrograman web sehingga lebih fleksibel disegi flatform operating system dan bahasa pemrograman berbasis mobile untuk mensuport jenis layanan pickup delivery 


\section{Daftar Pustaka}

[1] 2016. Perkiraan modal usaha jasa laundry kiloan dan prospeknya diambil dari http://wirabisnis.com/ perkiraan-modalusaha-jasa-laundry-kiloan-danprospeknya.html (31 Agustus 2016

[2] Susanto, Azhar. 2013. Sistem Informasi Akuntansi. Bandung : Lingga Jaya

[3] Sutarman. 2012. Pengantar Teknologi Informasi. Jakarta : Bumi Aksara.

[4] Jogiyanto,H.M. 2010. Analisis dan Desain Sistem Informasi. Yogyakarta : Andi Ofset

[5] Nasution,M.N. 2010, Manajemen Mutu Terpadu. Bogor : Ghalia Indonesia 